\title{
Maciej Drzewiecki
}

\section{STANDARD WYPOCZYNKU WE WSIACH LETNISKOWYCH W OCENIE WCZASOWICZOWW}

\section{LE STANDARD DU REPOS DANS LES VILLAGES ESTIVAUX APPRECIE PAR LES ESTIVANTS}

\begin{abstract}
Dans l'article, on a présenté les résultats des recherches d'enquête menées en 1982 dans 17 villages situés dans de différentes régions géographiques de la Pologne. Ces recherches ont eu pour but d'estimer le standard du repos offert par les villages accomplisisant les fonctions de récréation. Les opinions exprimées par les personnes se reposant daans ces villages ont servi de base à l'estimation. L'enquête a embrassé 173 familles, c. à d., 10\% environ des personnes se reposant dans les villages examinés.
\end{abstract}

Pobyt wczasowy w tradycyjnym, "prawdziwie wiejskim" środowisku przyrodniczym i kulturowym, od kilkudziesięciu lat stanowi na całym świecie jedną $\mathrm{z}$ bardziej atrakcyjnych form wypoczynku urlopowego. Problemy $\mathrm{z}$ nim związane są więc od dawna przedmiotem badań naukowych (R. Engelmann 1924, A. Mariotti 1933, 1974, S. Leszczycki 1936, G. Menges 1966, A. Kiesler 1968, P. Typiak 1972, M. Bonnea u 1973, W. Tomaszew $\dot{s}$ a 1974 , A. Soulier 1976, J. Michalak 1978, J. Warszyńska i A. Jackowski 1979, M. Drzewiecki 1980), przedsięwzięć organizacyjnych (związki i zrzeszenia hotelarskie w krajach alpejskich i Francji oraz w Polsce międzywojennej - L. A. Dę b s k i 1974), a wreszcie działań legislacyjnych państwa. W badaniach naukowych dużo miejsca poświęcono zagadnieniom ekonomicznym, zwłaszcza w aspekcie dochodów ludności miejscowej $\mathrm{z}$ tytułu rozwoju funkcji turystycznej oraz gospodarczym i społecznym skutkom ekspansji ludności miast na tereny wiejskie, ze szczególnym uwzględnieniem problemów "drugich domów". Stosunkowo najsłabiej rozpoznanym problemem jest czynnik sprawczy tych proce- 
sów - ludność miejska i jej preferencje w zakresie form i standardów wypoczynku na terenach wiejskich. Jednemu z fragmentów tego zagadnienia - jakim jest problematyka pożądanego standardu technicznego i środowiskowrego wsi, będącej miejscem wypoczynku - poświęcono główną część referowanej w tym artykule pracy badawczej.

Obok walorów poznawczych, uzyskana znajomość wymagań i życzeń wczasowiczów ma znaczenie dla właściwego ukierunkowania wszystkich form inicjowania i popierania rozwoju funkcji rekreacyjnej wsi: reklamy, informacji, planowania przestrzennego i gospodarczego oraz działań organizacyjnych i legislacyjnych.

\section{UWAGI POJĘCIOWE}

Przedmiotem badań były wsie o funkcjach rekreacyjnych, w których spędzają urlopy wczasowicze (tj. osoby przebywające $\mathrm{w}$ celach wypoczynkowych w miejscowości rekreacyjnej przez czas nie mniejszy niż ok. 2 tygodnie i nie korzystające $\mathrm{z}$ własnego domu lub sprzętu biwakowego), czasowo zamieszkujący w kwaterach prywatnych. Są to umeblowane pokoje wynajmowane we własnych mieszkaniach przez osoby zamieszkałe stale na wsi. Wczasowicze $\mathrm{z}$ reguły stołują się $\mathrm{w}$ stołówkach, restauracjach lub jadłodajniach niższych kategorii, część posiłków często przygotowują sami, z rzadka korzystają z urządzeń i obiektów usługowych.

Opisane wsie są nazywane - i to od kilkudziesięciu lat - wsiami letniskowymi. Pojęcie to - jeśli traktować je dosłownie - nie obejmuje wprawdzie małych miasteczek, pełniących od lat $\mathrm{z}$ powodzeniem analogiczne funkcje, jak również miejscowości górskich, w których wypoczynek odbywa się również zimą, ale $\mathrm{z}$ uwagi na silne zakorzenienie pojęcia w świadomości społecznej wydaje się słusznym pozostać przy starej nazwie. Do wsi letniskowych można zaliczyć tylko niewielkie wsie odznaczające się odpowiednimi walorami naturalnymi, uznanymi za niezbędne dla rekreacji, położone $\mathrm{w}$ zasięgu nieuciążliwego dojścia pieszego (wody, lasy) oraz z harmonijnym krajobrazem.

\section{PRZEDMIOT, ZAKRES I AKTUALNOSC BADAŃ}

Badania przedstawione $\mathrm{w}$ zarysie $\mathrm{w}$ tym artykule zrealizowano w Polsce w 1982 r. ${ }^{1}$ Objęto nimi zagadnienie standardu wyposażenia

1 Badania realizował w Instytucie Turystyki zespół ankieterów pod kierunkiem M. Drzewieckiego. 
i poziomu zagospodarowania wsi spełniających funkcje rekreacyjne, a ponadto koszty pobytu (dojazdu, noclegów, wyżywienia i rozrywek) oraz warunki podejmowania działalności usługowej (wynajmowanie kwater prywatnych, prowadzenie stołówek oraz zakładów gastronomicznych i handlowych). Dwa ostatnie tematy miały charakter wąsko aplikacyjny i straciły szybko swoją aktualność. Natomiast badania preferencji wczasowiczów zachowują swoje znaczenie poznawcze i wartość dla praktyki gospodarczej. Tendencje spoleczne $w$ tej mierze są dość stabilne, choć może zwiększenie zainteresowania wypoczynkiem na wsi spowodowała alienacja lat 1981-1982. Można sądzić, że nie istnieje wyraźniejsza zależność preferencji wypoczynkowych ludności od bieżącej sytuacji społeczno-gospodarczej (choć ta może nie zezwalać na realizację pożądanych modeli zachowań rekreacyjnych). Wskazuje na to fakt, iż w trakcie badań, prowadzonych w fazie najgłębszej recesji, nie stwierdzono istotnych zmian w strukturze społecznej, zawodowej czy dochodowej wczasowiczów w stosunku do tejże struktury obserwowanej w okresie prosperity gospodarczej w połowie lat siedemdziesiątych (M. Drzewiecki 1980).

Badania przeprowadzono w 17 wsiach (rys. 1), położonych w różnych strefach geograficznych ${ }^{2}$. Wsie te reprezentowały raczej zaawansowany poziom rozwoju funkcji rekreacyjnej, mierzonej bezwzględną ilością wczasowiczów i jej stosunkiem do liczby stałych mieszkańców. W ośmiu wsiach był on zbliżony do 1 , zaś $\mathrm{w}$ pozostałych był niższy $(0,2-1,0)$. Co do poziomu społeczno-gospodarczego wsie były znacznie zróżnicowane. Dwie z nich były małymi osadami rolniczymi (poniżej 200 mieszkańców), trzy były niedużymi wsiami o słabym zagospodarowaniu usługowym, zaś dwanaście było większymi lub dużymi wsiami, o zaludnieniu $1-3$ tys. osób $\mathrm{z}$ dobrym wyposażeniem $\mathrm{w}$ usługi i niektóre urządzenia oraz obiekty rekreacyjne. Taki dobór badanych miejscowości pozwolił na znaczne zobiektywizowanie wyników pracy poprzez uniezależnienie się od warunków miejscowych. Założenie to okazało się słuszne, gdyż mimo zróżnicowania wsi, opinie wczasowiczów były w poszczególnych miejscowościach zbliżone.

Preferencje wczasowiczów, co do charakteru wsi będących miejscem wypoczynku, badano za pomocą wywiadów przeprowadzonych przez zespoły ankieterów ze 173 głowami rodzin ${ }^{3}$, w skład których

2 Były to następujące wsie: Ostrowo nad morzem, Wiele, Rytel, Pile i Łubowo na Pojezierzu Zachodniopomorskim, Kruklanki, Wilkasy, Kosewo, Spychowo i Jabłonka na Pojezierzu Mazurskim, Pomiechówek w strefie nizinnej, Krasnobród w strefie wyżynnej oraz Kasinka, Witów, Ząb, Polańczyk i Lutowiska w strefie górskiej.

3 Badane osoby stanowiły szacunkowo niecałe $10 \%$ wszystkich wczasowiczów wypoczywających w analizowanych wsiach. 


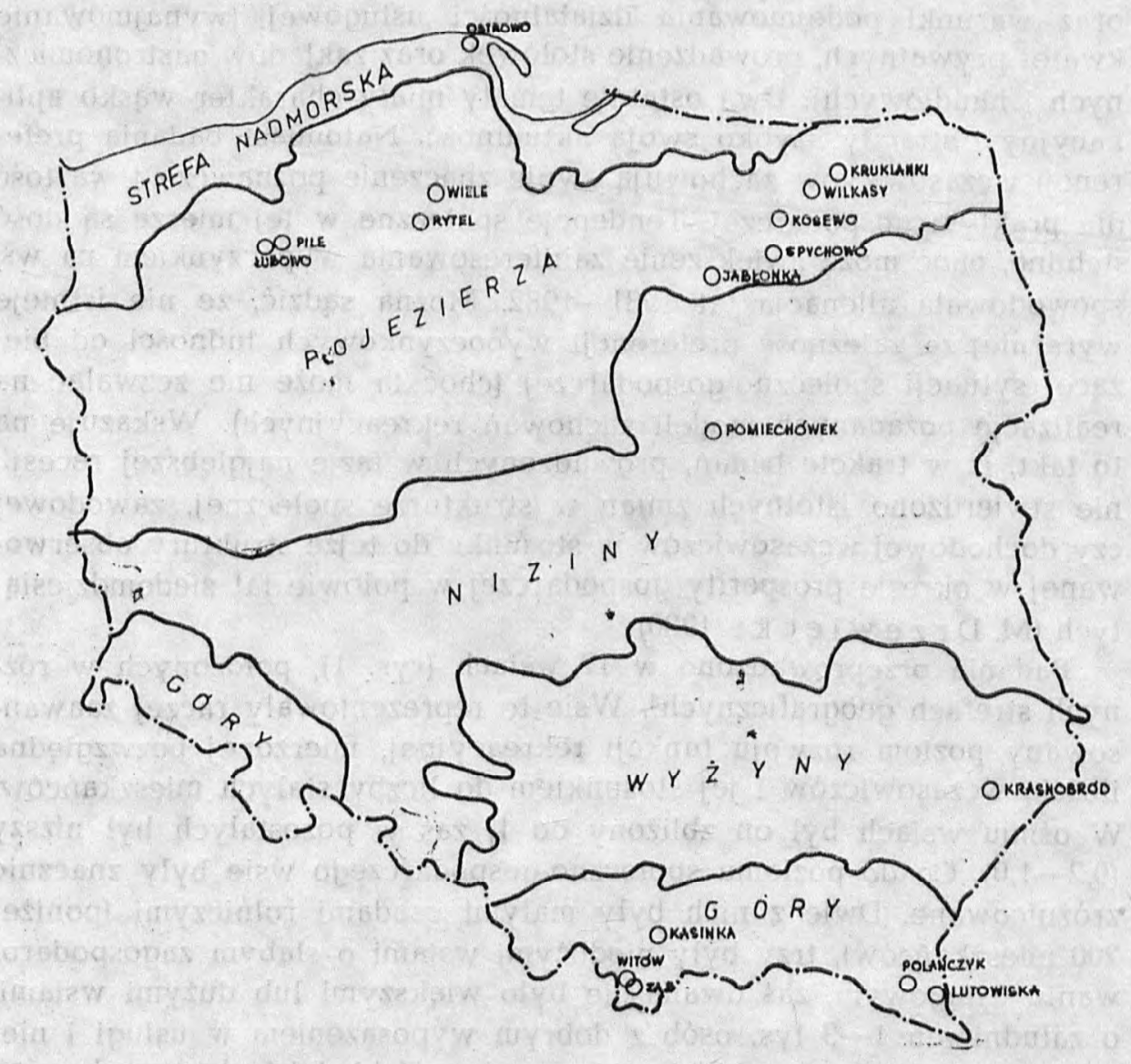

Rys. 1. Polożenie badanych wsi letniskowych w strefach geograficznych

Fig. 1. La situation des villages estivaux examinés dans les zones géographiques

wchodziło 415 osób przebywających wówczas w analizowanych miejscowościach. Wczasowicze ci pochodzili głównie z większych miast $87 \%$ przyjechało z miast powyżej 50 tys. mieszkańców. Reprezentowali oni środkową i dolną warstwę wykształconych i kierowniczych sfer społeczeństwa (tab. 1), jednakże o dochodach nie najwyższych, lecz raczej zbliżonych do przeciętnych.

Rodziny inteligenckie stanowiły $45,1 \%$ ankietowanych rodzin, podczas gdy w skali kraju osoby z wyższym wykształceniem stanowiły ok. 


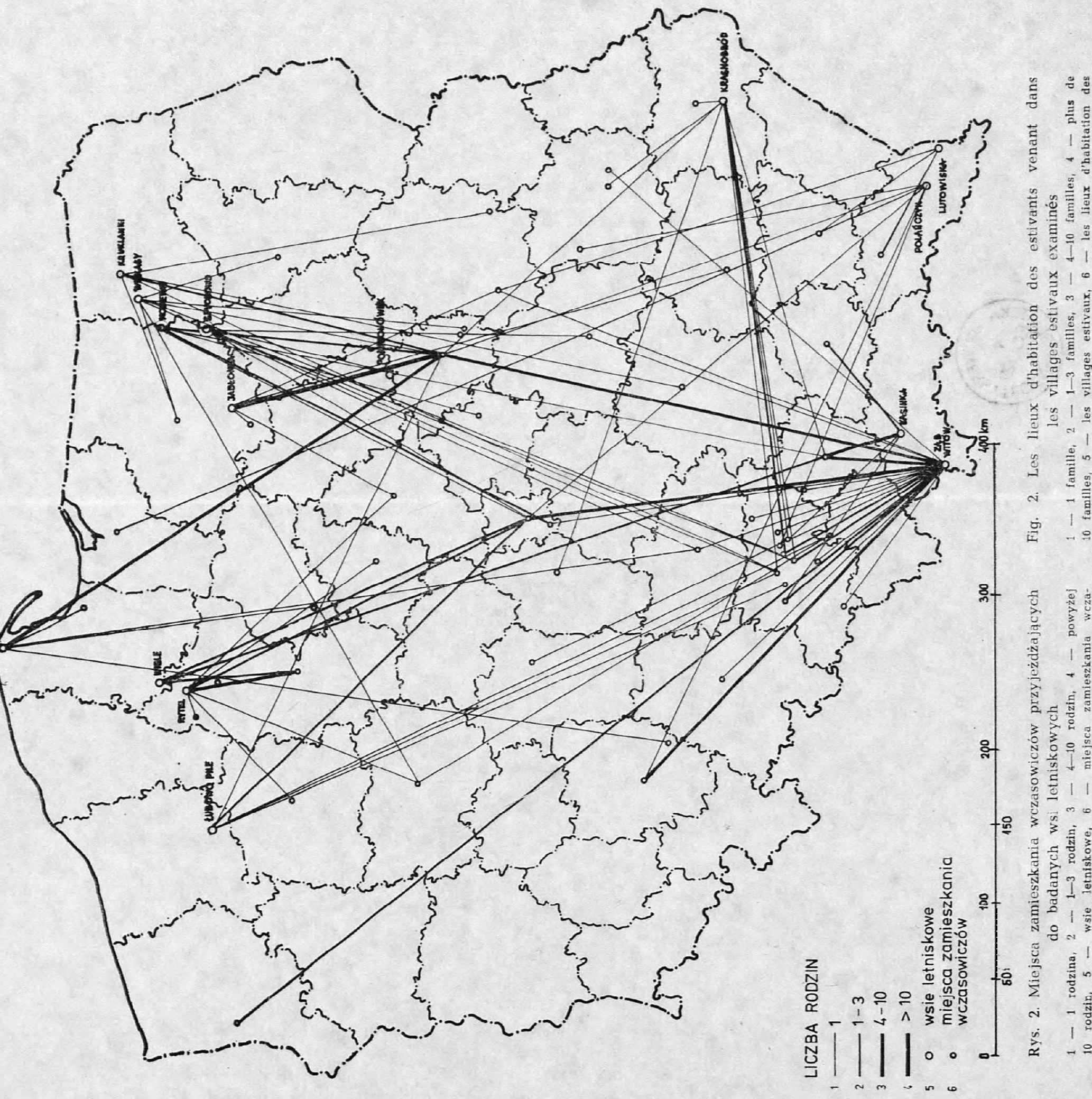


Pochodzenie ankietowanych rodzin wczasowiczów

L'origine des familles enquêtées des estivants

\begin{tabular}{|c|c|c|c|c|c|}
\hline \multirow{3}{*}{$\begin{array}{l}\text { Grupy ispołeczne } \\
\text { (wg pozycji głowy rodziny) } \\
\text { Les groupes sociaux } \\
\text { (selon la position de la tête } \\
\text { de famille) }\end{array}$} & \multicolumn{5}{|c|}{$\begin{array}{l}\text { Liczba rodzin } \\
\text { Le nombre des familles }\end{array}$} \\
\hline & rodziny & les familles & & $\begin{array}{l}\text { razem } \\
\text { au total }\end{array}$ & \\
\hline & $\begin{array}{l}\text { z dziećmi } \\
\text { avec } \\
\text { les enfants }\end{array}$ & $\begin{array}{c}\text { niepełne } \\
\text { incom- } \\
\text { plètes }\end{array}$ & $\begin{array}{c}\text { samotni } \\
\text { les solitaires }\end{array}$ & $\begin{array}{c}\text { liczby } \\
\text { bezwzględne } \\
\text { les nombres } \\
\text { absolus }\end{array}$ & $\%$ \\
\hline $\begin{array}{l}\text { Inteligenci* } \\
\text { Osoby średnio- }\end{array}$ & 30 & 36 & 12 & 78 & 45,1 \\
\hline $\begin{array}{l}\text { wykwalifikowan } \\
\text { Osoby nisko- }\end{array}$ & 46 & 21 & 20 & 87 & 50,3 \\
\hline wykwalifikowane & 5 & 2 & 1 & 8 & 4,6 \\
\hline Ogółem & 81. & 59 & 33 & 173 & 100,0 \\
\hline
\end{tabular}

* Osoby z wyższym wyksztalceniem oraz inne pracujące na samodzielnych, odpowiedzialnych stanowiskach.

5\% ludności. Jak wskazują badania zespołu A. Pawełczyńskiej (W. T oma szewsk a 1974) w 1972 r. inteligenci stanowili $23,3 \%$ wczasowiczów na wsi, zaś osoby średniokwalifikowane $68,1 \%$. Jest to więc specyficzna i tradycyjna "klientela" wsi letniskowych w Polsce.

Terytorialne pochodzenie wczasowiczów wskazuje, że odległość wsi od miejsca zamieszkania nie stanowiła istotnego kryterium wyboru miejsca wypoczynku urlopowego (rys. 2). Prawidłowość tę wyrażają liczby: do wszystkich badanych wsi $24 \%$ wczasowiczów przyjechało z odległości do $100 \mathrm{~km}, 26 \% \mathrm{z}$ odległości $100-200 \mathrm{~km}, 42 \% \mathrm{z}$ odległości $200-400 \mathrm{~km}$ i $8 \%$ z odległości dalszej niż $400 \mathrm{~km}$.

\section{WYNIKI BADAŃ}

Wczasowicze przebywający $w$ badanych wsiach letniskowych określili w ankietach, jakie pozytywne i negatywne cechy uważają za istotne dla dobrego wypoczynku i decydujące o wyborze danej miejscowości na miejsce wczasów. Uzyskano 480 odpowiedzi określających cechy pozytywne i 210 odpowiedzi dla cech negatywnych. Okazało się, że wczasowicze preferują głównie te cechy, które decydują o tradycyjnym charakterze terenów wiejskich, polegającym na braku przejawów urbanizacji i uprzemysłowienia, nawet $w$ ich początkowych fazach. 
Silne preferowanie tradycyjnych walorów wsi (ok. $44 \%$ odpowiedzi) zyskuje na ostrości, jeśli uwzględni się odrzucenie przez respondentów cech zaproponowanych $\mathrm{w}$ formularzu ankiety, a stanowiących przeciwieństwo tradycji: bliskość większego, atrakcyjnego pod względem wachlarza oferowanych usług ośrodka miejskiego lub obecność sklepów i urządzeń rozrywkowych na miejscu (poz. $6 \mathrm{w}$ tab. 2).

Tabela 2

Pozytywne cechy wczasów indywidualnych we wsiach letniskowych $\mathrm{w}$ opinii respondentów

Les traits positifs des loisirs individuels dans les villages estivaux selon les estivants questionnés

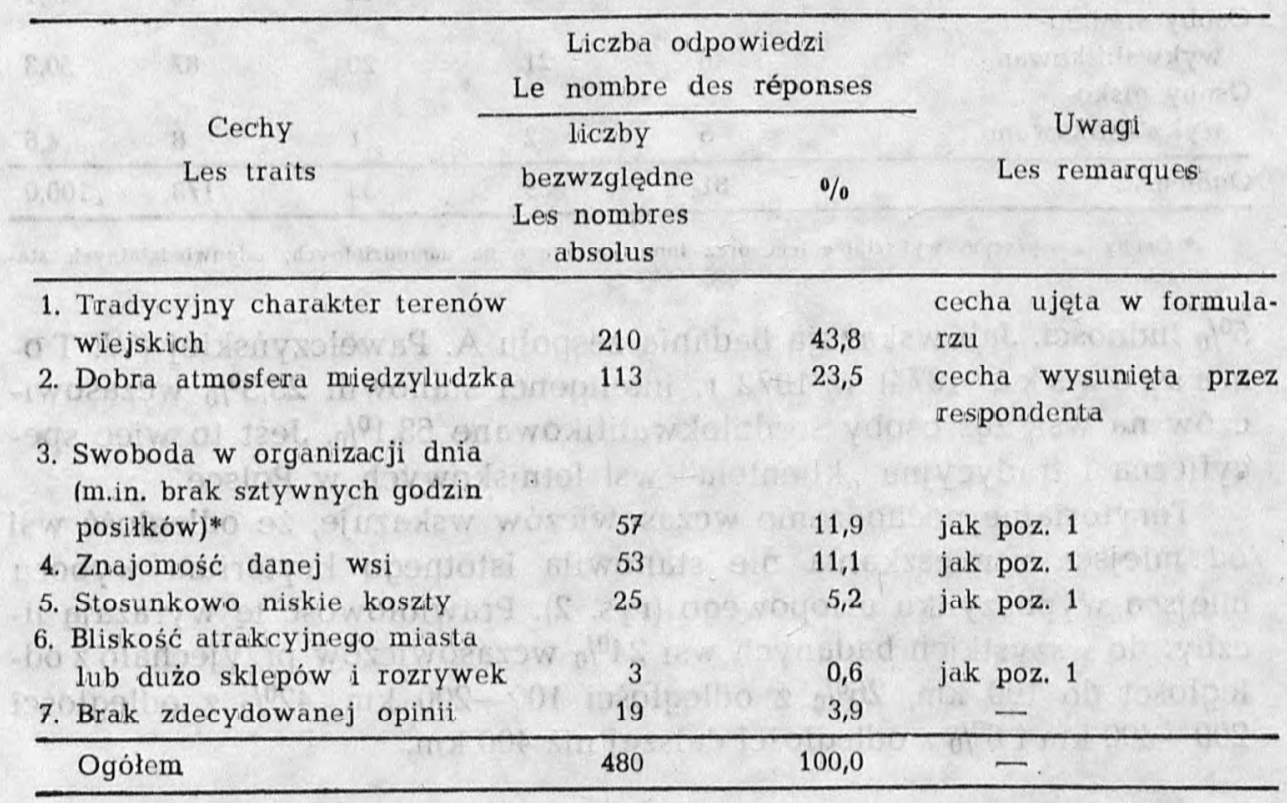

* W porównaniu z domami wczasowymi.

W stosunku do badania o 10 lat wcześniejszego (W. T o m a s z e wska 1974) występuje obecnie dalsza nobilitacja cech świadczących o upodobaniu do wypoczynku w środowisku prawdziwie wiejskim. W 1972 r. 51,1\% wczasowiczów we wsiach letniskowych określiło spokój i ciszę jako najbardziej potrzebne do dobrego wypoczynku. Jednocześnie aż $23 \%$ wczasowiczów poszukiwało wówczas rozrywki. Dziś grupa ta zmalała do nieistotnego marginesu, choć na rozrywki wydaje się dość dużo, bo ok. $8 \%$ całkowitych kosztów pobytu. Wyłoniła się natomiast nowa grupa walorów wsi letniskowych, obejmująca przyja- 
zne stosunki międzyludzkie, jakie zdaniem respondentów, łatwiej można znaleźć na wsi, niż w zbiurokratyzowanym i zformalizowanym dużym domu wczasowym.

Omawiana cecha dotyczyła dwóch kategorii osób: gospodarzy kwater prywatnych i współtowarzyszy wczasów. Życzliwość gospodarzy stwarza domową atmosferę, zæś utrudnia wypoczynek ich wścibskość czy nadmierne zainteresowanie życiem wczasowiczów, wreszcie skąpstwo, przejawiające się $w$ częstym kontrolowaniu zużycia prądu czy zabranianiu dzieciom zabaw, mogących spowodować wyimaginowane szkody.

Współtowarzyszy wczasów ocenia się głównie - choć nie wyłącznie - $\mathrm{z}$ punktu widzenia spokoju $\mathrm{w}$ kwaterze. Jako przyczynę braku spokoju wymienia się głównie nadużywanie alkoholu. Nie stwierdzono natomiast narzekań na głośne zachowanie się dzieci. Nie napotkano również na wymagania typu towarzyskiego w stosunku do sąsiadów wczasowych, jako ewentuälnych uczestników wspólnych rozrywek.

Czynnik ekonomiczny - wbrew przewidywaniom - nie został przez respondentów uznany za bardzo ważny. Cecha - stosunkowo niskie koszty uzyskała tylko $5,2 \%$ odpowiedzi. Wynika $\mathrm{z}$ tego, że w przekonaniu respondentów możliwość wypoczynku w środowisku wiejskim: cichym, w kontakcie z przyrodą i gospodarką rolną rekompensuje pewne niedogodności, także w zakresie kosztów.

Rozpatrzmy obecnie bliżej, najsilniej preferowane cechy tradycyjne wsi letniskowej, które otrzymały razem $44 \%$ głosów (tab. 2). W ramach nazwanego w ten sposób agregatu cech znalazły się 4 grupy walorów, z których możliwość kontaktu z przyrodą oraz cisza i spokój panujące na tradycyjnej wsi zostały uznane za jej najważniejsze zalety wypoczynkowe. Zwraca uwage dość wysoki odsetek osób $(12 \%)$, które - chyba nie przypadkiem - za ważną cechę pobytu na wsi uznają możliwość kontaktu z gospodarką rolną i zwierzętami oraz pracą w rolnictwie i hodowli. W opiniach opisowych, obok sentymentu do wspomnień z dzieciństwa (wszak ogromna część ludności miejskiej pochodzi ze wsi), jako motywów zainteresowania rolnictwem wskazywano także aspekty wychowawcze (ukazanie dzieciom trudu rolnika) i ekonomiczne (możliwość wynajęcia pokoju w zamian za pomoc gospodarzom).

Cechy negatywne, dyskwalifikujące wieś letniskową jako miejsce dobrego wypoczynku, ujęto w 11 grupach, z których 5 zaproponowano w kwestionariuszu ankiety, zaś 6 wymieniali sami respondenci (w różnym brzmieniu). Uzyskano łącznie 203 odpowiedzi. Wynika z nich, że najważniejszą bolączką pobytu na wsi jest jej niedostateczne zainwestowanie usługowe i rozrywkowe $(55 \%$ odpowiedzi). Stwierdzenie to 
Cechy tradycyjnej wsi preferowane przez ankietowanych wczasowiczów* Les traits du village traditionnel préférés par les estivants enquêtés

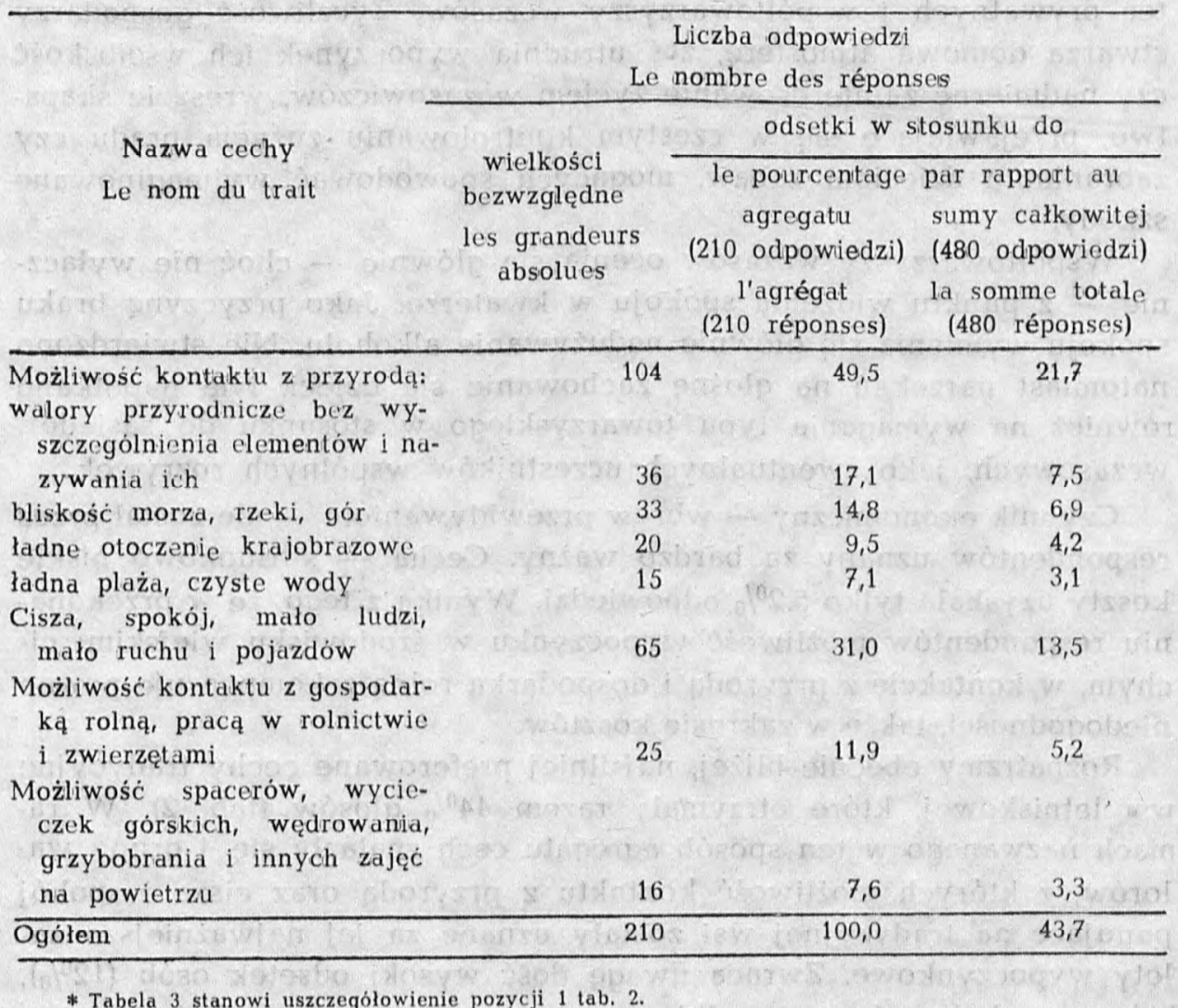

* Tabela 3 stanowi uszczególowienie pozycji 1 tab. 2 .

jest pozornie sprzeczne $\mathrm{z}$ dotychczasowymi konstatacjami, wymaga więc pewnego komentarza.

W warunkach silnych braków rynkowych latem 1982 r. opinii o potrzebie znacznego zainwestowania nie można uznać za wypływającą z rzeczywistych preferencji wczasowiczów. Skoro w ocenie cech pozytywnych walory zagospodarowania usługowego uzyskały zupełnie marginesowe znaczenie $(0,6 \%$ głosów), a jednocześnie jako cechę niepożądaną $11 \%$ wczasowiczów uznało zbytnią urbanizację (tab. 4), której objawem jest przecież także znaczne zagospodarowanie usługowe, to można przypuszczać, że w świadomości części respondentów wystąpiła identyfikacja ówczesnych braków zaopatrzenia $\mathrm{z}$ niedostatecznym zainwestowaniem usługowym.

Mniej istotne, niż sądzą niektórzy autorzy, okazały się złe warunki 
Niepożądane cechy wsi letniskowych

Les traits indésirables des villages estivaux

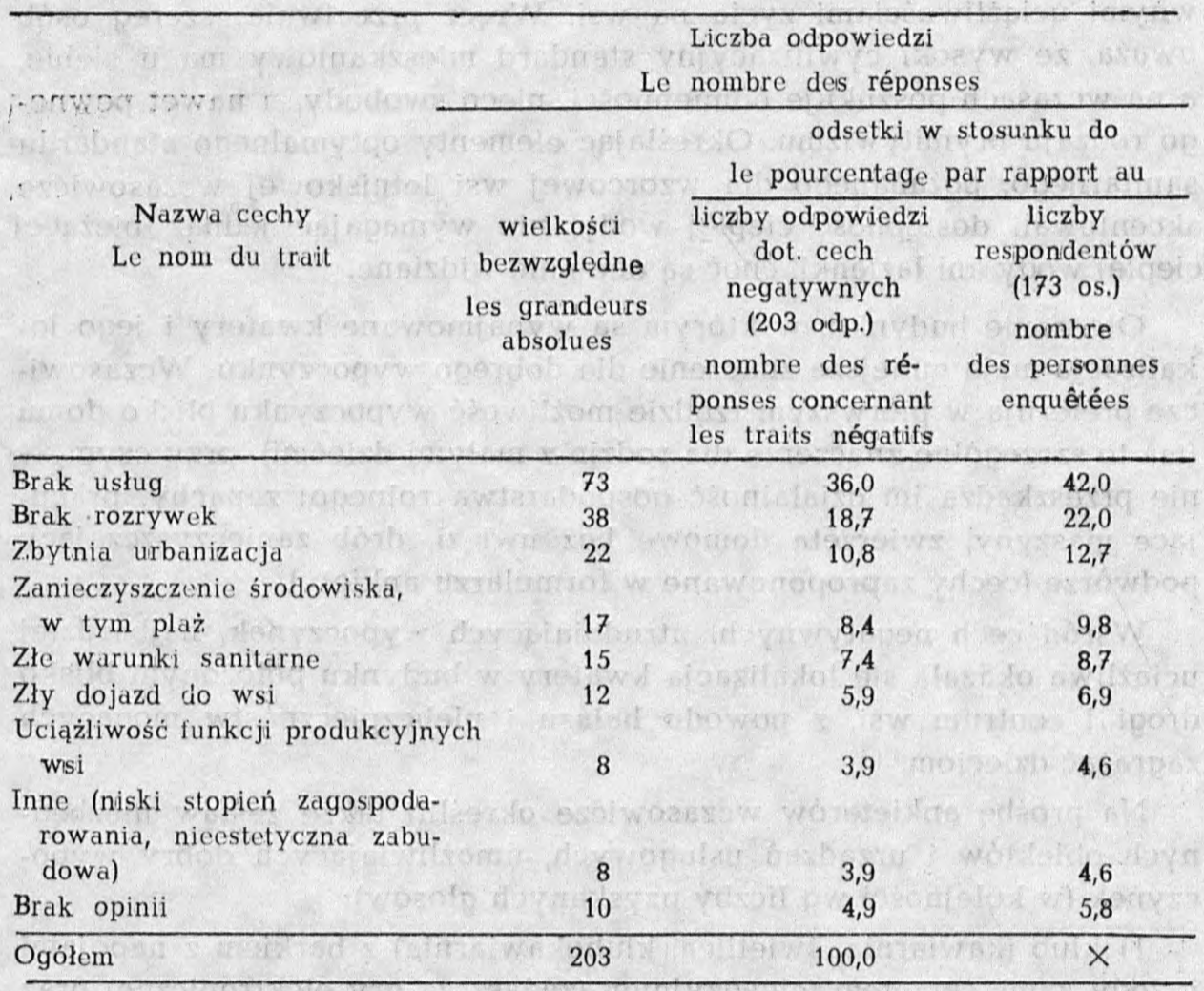

sanitarne wsi $(7,4 \%$ odpowiedzi). Dodajmy, że o warunkach sanitarnych samych pomieszczeń (kwater) mowa jest $\mathrm{w}$ dalszym ciągu artykułu.

Obok oceny warunków, jakim winna odpowiadać w przekonaniu respondentów wieś letniskowa jako całość, wypowiedzieli się oni również co do preferowanych cech samej kwatery. Charakterystyka taka obejmowała zarówno budynek, w którym są wynajmowane pokoje, jak i jego otoczenie: obejście gospodarskie i jego urządzenie wraz z lokalizacją budynku w stosunku do położenia walorów rekreacyjnych wsi.

Wymagania wczasowiczów w stosunku do budynku są dość skromne i obejmują czystość budynku i wynajmowanego pokoju oraz urządzeń sanitarnych. Jest to warunek najczęściej wysuwany, podkreślony jako niezbędny przez połowę respondentów (tab. 5). Natomiast nie jest bezwzględnie wymagany wysoki standard urządzeń sanitarnych (łazienka, ciepła woda, bieżąca woda, ustęp spłukiwny), choć oczywiście zajmuje 
wysokie, drugie miejsce i otrzymał $18 \%$ głosów. Podstawowe znaczenie dla oceny wymagań sanitarnych ma fakt, iż wybór wsi letniskowej na miejsce pobytu wczasowego jest zwykle decyzją świadomą. Osoby przyjeżdżające godzą się zatem $\mathrm{z}$ obniżonym standardem technicznym i pewnymi uciążliwościami życia na wsi. Wręcz przeciwnie: szereg osób uważa, że wysoki cywilizacyjny standard mieszkaniowy ma u siebie, a na wczasach poszukuje odmienności, nieco swobody, a nawet pewnego rodzaju prymitywizmu. Określając elementy optymalnego standardu sanitarnego, pożądanego dla wzorcowej wsi letniskowej wczasowicze akcentowali dostępność ciepłej wody, nie wymagając jednak bieżącej ciepłej wody ani łazienki, choć są one mile widziane.

Otoczenie budynku, w którym są wynajmowane kwatery i jego lokalizacja mają mniejsze znaczenie dla dobrego wypoczynku. Wczasowicze preferują w pierwszym rzędzie możliwość wypoczynku blisko domu (ma to szczególne znaczenie dla rodzin z małymi dziećmi), przy czym nie przeszkadza im działalność gospodarstwa rolneco: zapachy, pracujące maszyny, zwierzęta domowe bez uwięzi, drób zanieczyszczający podwórze (cechy zaproponowane w formularzu ankiety).

Wśród cech negatywnych, utrudniających wypoczynek, najbardziej uciążliwą okazała się lokalizacja kwatery w budynku położonym blisko drogi i centrum wsi, z powodu hałasu i niebezpieczeństw mogących zagrażać dzieciom.

$\mathrm{Na}$ prośbę ankieterów wczasowicze określili także zestaw niezbędnych obiektów i urządzeń usługowych, umożliwiających dobry wypoczynek (w kolejności wg liczby uzyskanych głosów):

1) klub (kawiarnia, świetlica, klubokawiarnia) z barkiem z napojami i słodyczami, sprzętem telewizyjnym (zwłaszcza gry elektroniczne) oraz możliwością urządzenia dyskotek młodzieżowych i wieczorków tanecznych dla starszych;

2) kiosk „Ruch" z poszerzonym asortymentem artykułów papierniczo-drogeryjno-pamiątkarsko-zabawkarskich;

3) kawiarnia tradycyjna;

4) punkty "małej gastronomii" (lodziarnie, smażalnie, rożna, ciastkarnie);

5) kioski owocowo-warzywne i z napojami.

Zestaw urządzeń usługowych zamieszczony w tab. 5 nie obejmuje obiektów uznanych za brezwzględnie konieczne: stołówek i sklepów spożywczych lub (co obecnie na wsi jest regułą) sklepów wielobranżowych (spożywczych $z$ uzupełniającymi stoiskami towarów przemysłowych). 
Preferowane cechy prywatnych kwater wynajmowanych na cele wczasowe

Les traits préférés des logements privés loués dans le but d'y passer les loisirs

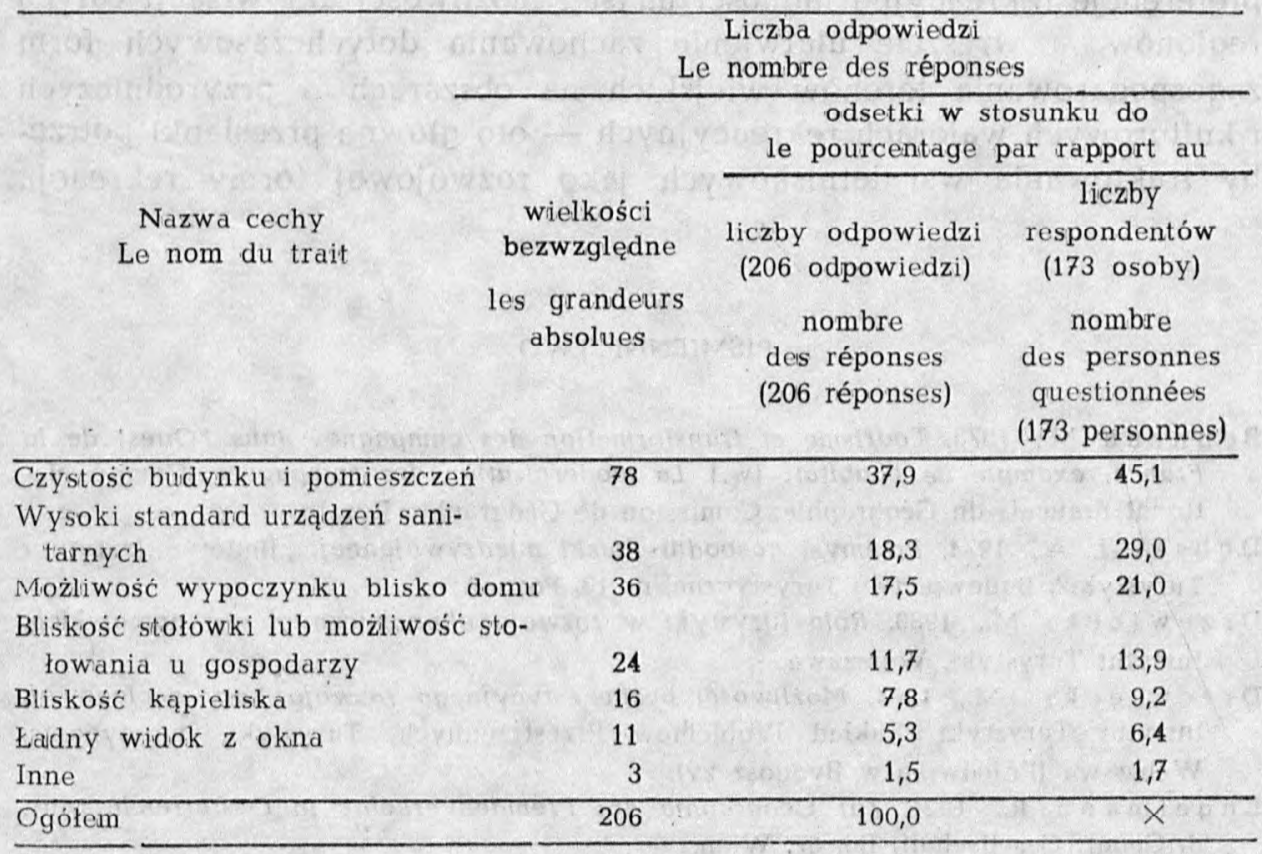

\section{ZAKONCZENIE}

Zainteresowanie wypoczynkiem we wsiach letniskowych w Polsce oraz podaż miejsc w kwaterach prywatnych ulegają od lat koniunkturalnym wahaniom, lecz generalnie jest to trend nieznacznie malejący. Komfort techniczny wypoczynku jest tu niższy niż w uspołecznionych domach wczasowych. Fakt, iż gospodarka prywatna jest uważana za sektor nierozwojowy powoduje, że w opinii społecznej utożsamia się gospodarkę prywatną z zacofaniem. Przesłanki te rodzą pogląd, że w przyszłości rację bytu mają jedynie duże, kompleksowo zagospodarowane, nowoczesne miejscowości i ośrodki wczasowe, wyspecjalizowane w pełnieniu funkcji rekreacyjnych, zaś wypoczynek we wsiach letniskowych może być tolerowany wyłącznie przejściowo, zastępując $\mathrm{z}$ konieczności nie $\mathrm{w}$ pełni na razie wykształconą sieć miejscowości wczasowych. Tymczasem wiele względów ekonomicznych i społecznych 
wskazuje, że głównie wsie $\mathrm{z}$ indywidualnie rozwinięlym rolnictwem mogą być $w$ przyszłości trwałym elementem zagospodarowania rekreacyjnego. Wykorzystanie wolnej zabudowy mieszkaniowej we wsiach wyludniających się, korzyści ekonomiczne dla ludności wiejskiej (M. Drzewiecki 1980, 1984, A. Kiesler 1968, P. Typiak 1972), preferencje rekreacyjne ludności miast i możliwości aktywizacji całych regionów, a wreszcie ułatwienie zachowania dotychczasowych form zagospodarowania terenów wiejskich na obszarach o przyrodniczych i kulturowych walorach rekreacyjnych - oto główne przesłanki potrzeby traktowania wsi letniskowych jako rozwojowej formy rekreacji.

\section{PISMIENNICTWO}

Bonnea u M., 1973, Tourisme et transformation des campagnes dans l'Quest de la France: exemple de l'habilat, [w:] La modernisation des campagnes, Comité National Francais de Géographie, Comission de Géographie Rurale.

Dębski L. A., 1974, Przemysł gospodni Polski międzywojennej, „Biuletyn Instytutu Turystyki", Budownictwo Turystyczne, nr 13, Poznań.

Drzewiecki M., 1980, Rola turystyki w rozwoju ekonomicznym wsi pomorskich, Instytut Turystyki, Warszawa.

Drzewiecki M., 1984, Możliwości bezinwestycyjnego rozwoju bazy noclegowej, Instytut Turystyki, Zakład Problemów Przestrzennych Turystyki, maszynopis, Wanszawa (Pracownia w Bydgoszczy).

Engelmann R., 1924, Zur Geographie des Fremdenverkehrs in Oesterreich, Mitt. d. Geogr. Geselischaft, Bd. 67, Wien.

Gołembski G., 1977, Rola handlu w obsłudze ruchu turystycznego, Instytut Tu. rystyki, Warszawa.

Kiesler A., 1968, Wplyw turystyki na dochodowość ludności (na przykładzie powialu nowotarskiego), "Problemy Ekonomiczne", nr 2, Kraków.

Konarski B., 1979, Próba przedstawienia statusu wsi letriskowej i jej modelu, "Koszalinskie Studia i Materiały", nr 4/28.

Leszczycki S., 1936, Badania nad ruchem letniskowym na Podhalu, [w:] Pamiętnik Polskiego Towarzystwa Balneologicznego, t. 15, Kraków.

Leszczycki S., 1975, Geografia jako nauka i wiedza stosowana, Warszawa.

Mariotti A., 1933, Corso di economia turistica, Novara.

Mariotiti A., 1974, Raccolta di siudi sul turismo, Rzym (Przybyszewska-Gudelis R. [rec.], 1976, Dorobek naukowy nesiora turyzmu we Wloszech Profesora Angelo Mariotti'ego, "Bivletyn Informacyjny Instytutu Turystyki", nr 1/29).

Menges G., 1966, Zur Ökonometrie des touristischen konsums. Ein okonometrisches Modell des Schwizerischen Konsums der Jahre 1929 bis 1959", Zeitschrift für Fremdenverkehr", H. 1.

Michalak J., 1978, Frzestrzenne zagospodarowanie wsi le'niskowych, Instytut Ksztaltowania Srodowiska, Warszawa.

Soulier A., 1976, Tourisme et agriculture dans L'arriére pays languedocien: le cas de la Montagne Herauitaise, Travaux du Centre Geographique d'Etudes et de Recherches Ruralas, nr 8, Université de Poitiers. 
Tomaszewska W., 1974, Wieś letniskowa - sondaż problemu, Centralny Ośrodek Informacji i Reklamy Turystycznej, Warszawa.

T y pi a k P., 1972, Wieś letniskowa, Warszawa.

Warszyńska J., Jackowski A., 1979, Podstawy geografii turyzmu, Warszawa.

Dr Maciej Drzewiecki

Instytut Turystyki

Oddział w Toruniu

Pracownia Zagospodarowania

Rejonów i Miejscowości Turystycznych

w Bydgoszczy

ul. Korczaka 6/55

85-319 Bydgoszcz
Wplynęło:

10 września 1986

\section{RESUME}

En faisant l'examen du standard de repos, on s'est servi de la méthode d'enquête dans 17 villages estivaux situés dans de différentes régions géographiques de la Pologne. On appelle villages estivaux de petites localités qui se distinguent par leurs qualités naturelles favorisant le repos (climat, eaux, forêts, paysage avec la préponderance des éléments naturelsi, et qui se trouvent dans un milieu exempt de vacarme et de pollution; les estivants y occupent des logements privés dans les maisons d'habitation de la population locale. L'examen se rapporte à l'an 1982, quand la situation sociale et économique de la Pologne était exceptionnellement difficile, mais il n'a pas perdu son actualité, parce que les préférences de la population urbaine en ce qui concerne le standard de repos sont extrêmement stabilisées.

Les 178 personnes enquêtées étaient désignées par le recours au hasard. C'étaient les têtes de famille sejjournant pendant l'enquête dans les villages examinés. Les familles se composaient de 415 personnes qui participaient aussi à l'enquête.

Dans les villages enquêtés, les estivants venaient principalement de grandes villes $(87 \%)$ et étaient représentants des couches moyenne et inférieure des sphères instruites et dirigeantes de la société.

Les estivants ont déclaré que le caractère traditionnel des terrains ruraux dépourvus de symptômes de l'urbanisation et de l'industrialisation c'était le trait du village estival le plus précieux et recherché par eux; ce trait distinguait le village de plus grandes localités et des maisons de repos appartenant aux établissements et constituant la forme la plus populaire de l'aménagement pour le repos de congé $(43 \%$ des réponses). Parmi d'autres traits, mieux déterminant le caractère traditionnel du village, on citait la possibilité du contact avec la nature (beau paysage, excursions, promenades, récolte des champignons, etc.) mise en relief par $21,7 \%$ des enquêtés, et le silence, le calme, le peu de passants et de voitures dans les rues (tab. 3). Il est à noter que $12 \%$ des enquêtés trouvent importante la possibilité du contact avec: l'économie agricole, le travail dans les champs et les animaux, en soulignant le rôle éducatif du séjour des enfants de ville dans un milieu campagnard. Les enquêtés ont confirmé la recherche d'un repos tranquille et "vraiment rust\&ue", en rejetant comme trait positif, proposé dans le formulaire de l'enquête, "le voisinage d'un magasins et des distractions sur place" $(0,6 \%$ des réponses). 
L'atmosphère cordiale, familiale et domestique (tab. 2) occupe la deuxième place parmi les traits positifs indispensables pour que le repos soit effectif et agréable. Il est impossible de créer une telle atmosphère dans une grande maison de repos bureaucratisée.

Les résultats des recherches danıs le domaine du standard technique exigé par les estivants sont aussi intéressants. On a constaté que les personnes enquêtées, quoiqu'elles apprécient positivement le haut standard technique, dans leurs opinions desariptives, trouvent indispensable le standard borné, modéré: la propreté du bâtiment, de la pièce, de la cuisine et des installations sanitaires, la fourniture de l'eau chaude par le propriétaire du logement (tab. 5).

On a aussi examiné les souhaits des estivants quant à l'aménagement du village estival. Les enquêtés ont déclaré qu'un tel village devait avoir un certain minimum des installations et des services, mais "l'urbanisation" excessive de la campagne (le caractère urbain de l'aménagement et de l'équipement de service) n'était pas désirable. Selon eux le minimum indispensable, à côté des magasins et des cantines, constituaient: un club-café avec l'appareillage de TV (les jeux électroniques) avec la possibilité d'organiser les discothèques pour la jeunesse, un kiosque avec la presse et l'assortiment élargi des bibelots et des articles papetiers et de droguerie. Les places suivantes ont été occupées par: le café, les points de petite gastronomie, les kiosques (les éventaires) offrant fruitis et légumes. On peut admettre que ce programme de l'aménagement ne perdra pas sson actualité pendant plusieurs années à venir.

Les recherches qu'on vient de présenter démontrent que le repos dans les villages estivaux gardant leur forme traditionnelle et la sphère bornée de l'aménagement continue à être un aspect attractif des loisirs pour les cercles de la société définis dans l'article et pour cela il doit être propagé. Cela favorisera l'activisation économique de plusieurs régions dont les possibilités de se développer sont restreintes et facilitera le maintient des formes actuelles de l'aménagement des terrains ruraux.

Traduit par Lucjan Kowalski

\section{SUMMARY}

The presented studies on standard of recreation were carried out by means of a questionnaire survey in 17 touristic villages situated in different geographical regions of Poland in 1982. The term to vristic villages is used to describe smal! villages possessing natural conditions favourable for recreation (climate, waters, forests, landscape with predominance of natural elements), and the environment free from noise and pollution, in which holiday-makers find accomodation in private residential houses of the local population. The studies were conducted in 1982, when the socio-economic situation of Poland was exceptionally difficult, however, they have not lost their relevance since preferences of the urban por.lation with regard to the standard to recreation in villages are extremely stable.

The sample consistad of 178 random chosen respondents, heads of families spending their vacation in the villages under survey during the period of the sizidios. These families consisted of 415 persons, who participated in the survey. 
The holiday-makers in the villages in question were coming mainly from bigger cities $\left(87^{\%} \%\right)$, and they represented a middle and lower stratum of educated and managerial spheres of the Polish society.

The holiday-makers admitted that the most valuable and sought by them characteristic feature of the touristic village is the traditional character of rural areas free from any sings of urbanization and industrialization $(43 \%$ of the responses), which distinguishes it from bigger locations and holiday centres belonging to enterprises being the most popular form of development of the countryside for holiday punposes. Among characteristios more typical for the traditional character of villages, the leading place is held by possibilities of contact with the nature (lovey landscape, excursions and walks, bathing, mushroom-picking, etc.) emphasized by $21.7 \%$ of the respondents, along with peace, quiet, small number of people, and little traffic (Tab. 3). It is worth noting that 12 per cent of the respondents declare that an important characteristic feature of touristic villages is a possibility of contact with agriculture, work on fields and with animals, stressing educational value of the stay of children from towns in the rural environment.

The fact that the respondents seek quiet and "truly rural" recreation has been confirmed by their rejection of "vicinity of an attractive town" or "a big number of stores and entertainments on the spot" $(0.6 \%$ of responses), which have been proposed as positive characteristics in the questionnaire.

The second place in evaluation of positive characteristics indispensable for effective and pleasant relaxation has gone to the cordial, family-like and "home" atmosphere (Tab. 2). Such relationships can hardly be developed in a big, oftentime bureaucraticized holiday centre.

The findings of the studies in the area of the technical standard required by the holiday-makers are equally interesting. It appears that although the respondents appraise positively a high technical standard, in their descriptive responses they consider limited standards to be indispensable. They include: cleanness of a building, their room and sanitation-kitchen facilities, as well as supply of warm water by the owner of the house (Tab. 5).

The object of the survey was also preferred mode of development of the touristic village. The respondents admitted that such a village should possess a certain indispensable minimum of service facilities considering, simultaneously, excessive "urbanization" of the village (urban type of building development and service facilities) to be undesirable. As a necessary minimum, apart from stores and canteens, the holiday-makers list: existence of a club-café with TV equipment (electronic games) and a possilility of arranging discotheques for young people or dancing parties, a bookstall with newspapers and an enlarged assortment of stationery, toiletries, and souvenirs. Further places were taken by cafés, snackbars, and fruit-and-vegetable stands. It can be accepted that this programme of development of touristic villages will be valid within the next ten years or so.

The presented studies show that holiday recreation in touristic villages, in their traditional shape and with their limited degree of development, will continue to be an attractive form of spending vacation time for the social groups described in this article and, as such, it should be supported. This should contribute to economic activation of numerous regions, which do not have any major chances for development, and it will facilitate preservation of traditional forms of development of rural areas. 